"IN ITS OWN IMAGE": FASHIONING THE CANADIAN MULTICULTURAL MIRAGE IN FOOD PRODUCTION, CONSUMPTION, AND EQUALITY

Jenelle-Lara Gonzales, BA, University of Guelph, 2008.

A Major Research Paper

presented to Ryerson University

In partial fulfilment of the requirements for the degree of

Master of Arts

in the Program of

Immigration and Settlement Studies

Toronto, Ontario, Canada 2010

(C) Jenelle-Lara Gonzales 2010 


\section{Author's Declaration}

I hereby declare that I am the sole author of this major research paper.

I authorize Ryerson University to lend this paper to other institutions or individuals for the purpose of scholarly research.

Ifurther authorize Ryerson University to reproduce this paper by photocopying or by other means, in total or in part, at the request of other institutions or individuals for the purpose of scholarly research. 


\title{
"IN ITS OWN IMAGE": FASHIONING THE CANADIAN MULTICULTURAL MIRAGE IN FOOD PRODUCTION, CONSUMPTION, AND EQUALITY
}

Jenelle-Lara Gonzales

Master of Arts, 2010

Immigration and Settlement Studies

Ryerson University

\begin{abstract}
With bucolic imaginings, it is commonplace to lament the social and physical distance that separates us from the production of our food. In a dystopic distanciation, food becomes a static product—commodified, fetishized, and objectified—while our relationship to it, increasingly antagonistic. Indeed, food provides a unique aperture into the 'malaises of modernity' (Taylor 1991) when 'simple' questions in fact reveal complex dynamics, processes, and symptoms covering a range of questions: From what is our food made? From where? And by whom? In highlighting the dialectic of the selective mobility of producers, the unrestricted mobility of commodities and capital, and the immobility of land, this paper draws linkages between food, labour and migration through an analysis of their ordering principles that affront the 'privilege' of Canadian citizenship, the rights it confers, and the responsibilities it demands. For the study of immigration and settlement in Canada or more

globally, Canada's active role in shaping the life conditions of the migrants it receives, these lines of inquiry cannot be ignored.
\end{abstract}

Key words: immigrants, food, multiculturalism, production-consumption, inequality 


\section{Acknowledgements}

To my family for being my anchor.

To Alex for buoying me through and for better tomorrows.

"Let us not be bitter about the past, but let us keep our eyes firmly on the future. Let us remember that there is no blessing so sweet as life and liberty. Let us remember that the stature of all mankind is diminished so long as nations or parts of nations are still unfree. Let us remember that the highest purpose of man is the liberation of man from his bonds of fear, his bonds of poverty, the liberation of man from the physical, spiritual and intellectual bonds which have for long stunted the development of humanity's majority".

Ahmed Sukarno, Bandung, Indonesia 
I. INTRODUCTION

Knowing food and growing food: towards a

theory of the middle-ground

In defense of food: why food matters

for the study of immigration

Super Foods and Powerful Policies:

The Relationship between Food and Multiculturalism

II. MAPPING THE TERRAIN: BRIDGING ECONOMIC

IDEOLOGIES AND POLITICAL INSTITUTIONS THROUGH

HISTORICAL STRUCTURALISM

III. IDEOLOGIES: FENCES OF THEORY AND

WINDOWS INTO PRACTICE

Food as Cultural Currency: Buying and

Settling for Recognition

Rising Tides, Sinking Ships: Neoliberalism as Ideology

IV. THE ILL-LIBERTY OF INSTITUTIONS: CANADA'S

IMMIGRATION SYSTEM AND THE MULTICULTURAL

EMOLLIENT OF DIVERSITY

Conditional Permanency, Permanent conditionality:

Immigrant Status and Labour

V. MATERIAL CAPABILITIES: PROFITABLE AND

POWERFUL FOOD

VI. CONCLUSIONS: MIRAGE MULTICULTURALISM, A SOLVENT PROMISE

VII. WORKS CITED 
My being-in-the-world or my 'place in the sun', my being at home, have these not also been the usurpation of spaces belonging to the other man whom I have already oppressed or starved, or driven out into a third world; are they not acts of repulsing, excluding, exiling, stripping, killing?

Emmanuel Levinas, Ethics as First Philosopby (1989, p.82)

Mobility entails extraordinary promise and peril. Within Immigration and Settlement Studies, one must nuance the relationship between the state, the market, and the migrants themselves to capture the depth and breadth of the issues of power, prosperity, inequality, and injustice that this opportunity affords. This is especially true given that discussions of state sovereignty are increasingly limited to control over state borders from 'the immigrant threat'. Indeed, as Saskia Sassen (1996) confirms, "economic globalization denationalizes national economies; in contrast, immigration is renationalizing politics" (p. 59). Therefore, because the regulation of people and borders is at the fore of questions of state sovereignty, a central starting point to bridging nationalized promises and denationalized imperatives is an analysis of the contradictions that arise from this disjuncture. One such contradiction is the differential mobility of capital and goods (commodities) and the selected mobility of people.

While seemingly intuitive-people present threats that goods do not-this paradox reveals much about where, how and what kind of power operate at various scales: from the personal to the provincial, national, and transnational. Differential mobility also reveals much about the nature of power-cultural, economic, and ideological-and the importance accorded to each. While seemingly equal, some forms of power are qualitatively and quantitatively more important than other forms. Economic power is one such example. Power in this form is amorphous; intending to obfuscate, confuse and remain concentrated such that decisions of many are made in the hands of few. Indeed, for its effective operation, it 
must either be hidden or hide other power. Such is the case of food for the study of immigration.

The production and consumption of food provides a revelatory lens through which we can understand capitalist déroulement through its operative powers-economic, cultural, and ideological-in producing inequality. This is because food is power both literally and symbolically. As a necessary commodity for life itself, food begets profit. As a signifier—of culture, tradition, patrimony, and more essentially of individual and collective identity-food informs provocative questions about the power of profit over people. In this way, the study of food as related to immigration demonstrates the ways in which people are increasingly treated as commodities through a valorization of their productive capacities, and the perversion of capital to surreptitiously appropriate these identities into profit. Therefore, by now, if people are seen as commodities, the mobility of both food and immigrants should nominally be equal under state policies—but they are not.

Commodities move freely but people cannot. Why is this so? As the reciprocal of the former, why do food commodities achieve permanency while only select immigrants can hope for the same? How is this paradox compounded by the immobility of land? Is this antinomy the cause or consequence of the differential valorization of people and things under capitalism?

These broad questions provide the canvas for this analysis. Framed in another way, I ask: what can food tell us about the state-sponsored pursuance of people as profit and consequently, profit as power for the regulation of migration. Such is the crux of the present analysis. Drawing from an historical structuralist approach, this paper argues that through the differential treatment of people through immigration policies and the skewed production-consumption chains in agricultural policy, the Canadian state immobilizes some 
at the expense of others. For this reason, it is not as it claims to be, the neutral arbitrator in state-market relations. Contrarily, in the pursuance of profit over people, the Canadian state capitalizes on and contributes to bourgeoning global injustice by "producing in its own image". That is, if the face of Canada is multicultural but lacking substantive equality, producing in this way gives the illusion of unity in difference from afar, only to discover "all that is solid melts into air"-such is the mirage of multiculturalism.

Following this line of logic, this essay illustrates three interrelated claims. The first, is that immigrants are increasingly viewed as commodities-their labour and cultural contributions are always-already subsumed into an economic and/or political logic to bolster state legitimacy. Second, a crisis of state legitimacy occurs when rights are not respected and state responsibility is relinquished, lending to an interference of the state in some areas and a retrenchment in others. Third, this interference as an attempt to serve two masters-its supposed sovereignty and people - has undermined the former and commodified the latter.

The essay is organized into the following sections. First, I defend the importance of food for immigration and settlement studies in theory and in practise. From this, the salience of class based analysis is highlighted when analyzing the 'privilege' of Canadian citizenship, the rights it confers and the responsibilities it demands. It is argued that a class based approach, linked to a more nuanced approach that is sensitive to the challenges of race, ethnicity and gender, can and does illuminate the more complex and hidden facets of the two interrelated cycles at the heart of this paper -the global production-consumption cycle of food as a commodity and the more restricted cycle of global labour circulation. For the study of immigration and settlement in Canada or more globally, Canada's active role in shaping the life conditions of the migrants it receives, these lines of inquiry cannot be ignored. 
Based on Robert Cox's historical structure model, I then advance a reconstituted notion of food by unpacking the relationship between people and food and then repackaging this relationship in the context of the ideologies and the state. To do so, I explicate the relationship between ideology and liberal institutions, by presenting a typology of ideologies by Slovenian philosopher Slavoj Zizek. This section challenges the ideologies of commodity fetishism, multiculturalism, and neoliberalism as linked to their manifestation in immigration and agricultural policies. Using an analysis of immigration and agricultural policies, subsequent sections problematize Canada's involvement in creating a demand, production, and consumption cycle which fuels the Canadian economy by instrumentalizing people. To this end, the final section will provide the thrust of the argument that Canada, through its mores of neoliberalism ${ }^{1,}$ mirrors global inequality and reproduces it by attempting to fashion others, nationally and internationally, "in its own image".

Finally, this work is underpinned by a set of convictions and cares composing an insistent vision of another way of political life. Essentially, it is concerned with freedom and equality. That is, despite its tattered philosophical and political premises, I believe this intellectual and practical pursuit worthwhile as this essay is "the intellectual side of emancipation".

As such, it is with a non-negotiable minimum to "share in power rather than be protected from its excesses, to generate futures together rather than navigate or survive them" (Brown, 1995, p.4) that this critique proceeds.

\footnotetext{
'Neoliberalism here is an ideology and practise. As an ideology, neoliberalism holds that the key to wealth is understood as an operational set of policies made up of economic concerns (including internationalization of production, opening of financial markets, increased mobility of transnational corporations, and an overall deepening of the global market mechanism), ideological changes (stressing trade liberalization and private enterprise), and cultural changes (entailing a spread in consumerism and a gradual homogenization of world cultures [Bray \& Bray, 2002].
} 
Turning history on its head opens up whole new worlds of possibility. -Howard Zinn as cited by Prashad, 2007, p. iv

It seems that this epoch is one of firsts and 'crises'. For the first time in history, those who are overweight outnumber those who are hungry (Patel 2007). For the first time in history, there are 175 million people living outside their country of origin, prompting some to cite international migration at its 'historical zenith' (Messina \& Lahav, 2006). For the first time in history, the world population is more urban than rural (Patel 2007).

Ours is also described as an age of 'ecological crisis', 'migration crisis', 'food crisis' 'farm income crisis', 'AIDS crisis', 'population crisis', 'democratic crisis' and so forth. And yet for all that is 'new' in the history of the global economy, equally one must not forget what is instructive in the old. Indeed, fervent preoccupation with what is new ${ }^{2}$ necessarily implies analysis via particularism; such endless differentiation unnecessarily negates universal, 'eternal ideas' (Badiou as quoted by Zizek 2002). Two that come to mind are: first, the universal need for food, which cuts across sociological divisions. Second, human history has always experienced the dialectic between inequality and emancipation. The dialectic, in Hegelian terms, is any situation gives rise to its own contradiction. (Badiou as cited in Zizek 2002).

Arguably, freedom from inequality and struggle for emancipation are the "most general and common in the sequences of changes undergone by human nature and institutions" (Vico as cited by Cox, 1981, p. 94). Because I adhere to what is enduring in the old (plus ga change...), I undertake a dialectical analysis to understand both the reality and the governance of mobility. To do so on the level of logic means seeking truth through the

\footnotetext{
${ }^{2} \mathrm{New}$, in this sense is writ large. Here, I refer to what is 'new' or 'novel' in terms of theory, assumptions, epistemological positions, paradigms, statistics, phenomena and so forth.
} 
exploration of contradictions (Cox, 1981, p. 95); and in this case, the paradox between the mobility of commodities, the selected mobility of producers, and the immobility of land. In other words, understanding the dialectic of mobility or permanency for some at the exclusion of others provides insights into its constituent elements: domination, exploitation and alienation. The dialectic, as 'an eternal idea', does not imply reification, crystallization, or a grand narrative. Rather, as Cox notes, "one aspect of this is the continual confrontation of concepts with the reality they are supposed to represent and their adjustment to this reality as it continually changes" (1981, p. 95). Before proceeding without purpose, it is necessary to outline why the sensitivities of immigration studies should concern themselves with food.

\section{IN DEFENSE OF FOOD: WHY FOOD MATTERS FOR THE STUDY OF IMMIGRATION}

To begin, a naïve but important look at why food matters for the study of immigration. Arguably, 'ethnicized' food is the grout of the Canadian mosaic. It serves as both, a divisive line between distinct tiles of Canada's ethnic composition and as a binding agent, holding the mosaic together. It is at once, an inviting factor-an entrée into new sensory experiences — and an isolating one, that signals difference and inequality. As a means to and symbol of 'cultural capital' (Bourdieu 1988) the exploration of new foods facilitates gustatory meandering, signals palatal sophistication and worldliness (Appadurai 1988). Yet for Others, whose very 'worldliness' qua accent, dress is their same prison ${ }^{3}$, "food is of central importance in maintaining connections to home, and signifying ethic identity among diasporic community members" (Vallinatos \& Raine, 2008, p. 355). What is significant here is that while many enjoy the increased diversity, availability and richness of 'ethnic' cuisine because of migration, its meanings and affiliations for some are stronger than others, reflecting an underlying power differential.

\footnotetext{
${ }^{3}$ Worldliness here is meant in the sense of markers of difference, phenotypical, also in dress, accent, religious beliefs, economic status, and so forth.
} 
Despite its quotidian familiarity food remains problematic as an object of inquiry and in real lives (Koc, 2008). As a subject of academic inquiry, food analyses are revelatory expressions of the ongoing sociological debates between structure and agency, production and consumption, culture and identity. The latter have been captured by recent literature in the transitional urbanism vein of migration studies which theoretically scrutinizes the "mundane and situated efforts by which people make their lives across international borders" (Conrad \& Latham, 2005, p. 227). By most accounts, the preparation and consumption of ethnicized food is one such situated effort to recreate the familiar (home) in the foreign (host country). It is important to note that ethnic food is understood not as an objective category but as an assignation in comparison to foods and eating habits associated with the dominant Anglo-Saxon culture in Canada.

To explain, precisely because food is embedded within lived understandings of culture and identity, it is important in real lives. As necessary for all life, food is inherently a political question because its production, access and consumption are unequal. For immigrants specifically, food is central to the mediation of the settlement experience given that "migration to a new country often results in a variety of social and economic challenges, reflected in foodways" (Vallinatos et al., 2008, p. 356). More calamitously, the erosion, loss or even dilution of customary culinary practices is grave; equated with the "abandon[ment of] community, family, and religion" (Gabaccia as cited in Vallinatos \& Raine, 2008, p. 357 ). What can explain the symbolic salience of food for immigrants? If food "belongs unambiguously on the side of the bodily, the temporal, and the quotidian" then why is a loss of foodways also a loss of a way of being? (Heldke, 2006 p. 202). Drawing from Barthes' (1961) seminal contribution, food is not just a thing sensu strictu, nor its production and consumption mere processes. Instead, food is a signifying practice - for him:, 
Food is also, and at the same time, a system of communication, a body of images a protocol of usages, situations, and behaviour...substances, techniques of preparation, habits, all become part of a system of difference in signification; and as soon as this happens we have communication by way of food (Barthes as cited in Counihan and Esterik, 2008, p. 29-30).

Put another way, food carries, connotes and confers multiple meanings. Moving from a mere physical need, food in context carries a system of communication. As a mechanism of conspicuous consumption in aspirations for distinction (Bourdieu 1988), privileged consumers literally "buy/bite in" to this palatable promise. In this way, food is both a literal embodiment of and an apt metaphor for the relationship between culture and the individuals who comprise it. And herein lies its power.

\section{Super foods and Powerful Policies: The Relationship Between Food AND MULTICULTURALISM}

Because food is exploitable, as sustenance that cannot be separated from identity, it is highly valuable. For this reason, it can also be fetishized, commodified, and resold to the Canadian born who 'eat the Other' (hooks 1992) through ethnic cuisine. It can be profitable for those whose collective identities are based on shared foodways; lending credence to the "the notion of multiculturalism as food [as] often the most benign version of accommodating cultural difference" (Gunew, 2000, p. 227). And herein lies its significance for multicultural policy, revealing the mirage of multiculturalism as state policy and ideal. To explain, in casting food as ersatz gustatory cosmopolitanism, the economic power relations it subsumes and expresses are obscured. That is, such a view does not take into account inequality which dictates who will produce for whom and for which markets. Furthermore, food as multiculturalism obscures the ways in which access to mobility, physical and social, is differential between and among people and things. In short, who can eat what and where is not benign. Therefore, the third reason why food is important for the study of immigration 
is this: since food is already commodified and people increasingly so, an analysis of this evolving relationship highlights the explicit class dimension soldering the two, an insight undertheorized by postmodern multicultural politics.

To trace a theoretical genealogy, it is well known that the very gesture of drawing a line of distinction between the political and the apolitical is itself a political gesture par excellence as much feminist scholarship has alerted us to so lucidly. The discursive separation itself indicates an attempt to maintain the legitimacy of state intervention or lack thereof, in domains ascribed the 'political' precisely by depoliticizing the 'apolitical'. What if however, in attempting to politicize identarian struggles the effect was to suspend analysis of the very conditions that structure these antagonisms?

That is to say, such a conceptual move, politicizing the personal (the personal is political) corresponded to the programmatic attack of the welfare state since the 1970 s under the ethos of the Washington Consensus (structural adjustment), to the end of 'actually existing socialisms' in the late $1980 \mathrm{~s}$, and to the consequent retreat of the Left from the seemingly deterministic economism of Marx. Thus, in trying to avoid essentialism and the sins of omission of Marx, scholars of the 'Left' adapted a 'radical' anti-essentialism as the sine qua non (Mouffe and Laclau 2004 as cited by Gilbert 2008). In this formation, class was no longer the 'only' oppression but one of a series: race, gender, sexuality, etc. Issues then became framed in terms of the resultant racism, patriarchy, sexism, ableism, etc that stem from a capitalist economy as opposed to the root of inequality which is class itself. Importantly though, "to speak of a postmodern [identity] as specific configurations and representations of social, economic, and political life is not (yet) to take a political position on it or within it, nor even to adopt... a particular 'sensibility' (Brown, 1995, p. 32). Such recalcitrance to the race-gender-class triptych can be explained by the misrecognition of class 
as but one part of the series production-distribution-exchange-consumption instead of its role as a 'structuring principle' as well (Zizek, 2000, p. 96). That is, class is simultaneously one of the terms but it is also the anchoring term. And considering that paid work has trumped all other ways of economic life under global capitalism, its importance cannot be understated. For this reason, class is not simply another ideology legitimating oppression; it denotes exploitative relations between people mediated by their relations to the means of production and in the neoliberal world order, therefore their economic existence (Gimenez 2001, p.25).

A clear example of analyses in which economic concerns are subsumed into cultural questions can be found in accounts on the relationship between food and immigrants in the transnational migration literature. ${ }^{4}$ Such accounts, which express "food as identity" or food as a signifier for home, the familiar, home country nostalgia and host country anxieties, are underpinned by a Foucaultian understanding of power, as diffuse and manifest at the bottom (Foucault 1990). If power is manifest at the bottom it follows then that resistance to power can also be encountered at the bottom. In this view, individuals can be empowered because their gendered, racialized, and classed identities are not only individual attributes but must also be 'performed' while interacting with others. Thus, during performativity or 'doing difference', scripts can be subverted, ascribed identities can be manipulated, and roles can be inverted. In this way, when transnational community members express their 'hybridity', they successfully navigate and choose which identity is best and when between the two. In the process, migrants exercise their agency by subverting hegemonic scripts ascribed to them.

These accounts, while undoubtedly important in individual registers of belonging and comfort, are not unproblematic. This is because when empowerment locates an

\footnotetext{
${ }^{4}$ cf. Lessa \& Rocha (2009), Hernandez-Ramdwar (2008), Vallinatos \& Raine (2008), Avakian (2005).
} 
individual's sense of worth and capacity within the specter of individual feelings, said empowerment radically decontextualizes the subject; which is key to the fictional sovereign individualism of liberalism (Brown, 1995, p. 22-23). In other words, 'destabilizing' and 'disrupting' notions of culture reasserts the fundamental claim of neoliberal ideology: we are all individuals, free to choose our destinies, which signals an oddly adaptive and harmonious relationship with domination to choose judiciously between identities since not all identities are 'created equally' (Gilbert, 2008, p. 562 and Brown, 1995, p. 22). Furthermore, such 'performativity' contributes to the reproduction of these structures. The point here is that celebratory images of transnational communities as transgressive or post-national, must be nuanced because "such romantic yearnings for a new revolutionary subject tend to obscure the ongoing power relations underpinning the formation and reproduction of states, capitals, national, and transnational identities" (Smith, 2005, p. 238).

Multiculturalism then as a problem between the expression of contentious identities involves a theoretical retreat from the problem of domination within capitalism. And it is "in this silent suspension of class analysis, that we are dealing with an exemplary case of the mechanism of ideological displacement" (Zizek, 2000, p. 97). Therefore, when class antagonism is disavowed, when its key structuring role is suspended, "other markers of social difference may come to bear an inordinate weight." (Brown 1995, p. 60).

The postmodern "ideological displacement," then, is the shift of the parameters of the political discussion from the ontological to the contingent, that is, from the primordial essence of inequality to its temporal symptoms. In concrete terms, when food is understood as multiculturalism (celebratory song and dance accounts of the plurality and co-existance of diverse cultures) and multiculturalism is understood as the denial of the full expression of cultural identities (only that which is palatable to dominant Anglo-Saxon sensitivities is 
recognized as worthy of integration), economic issues become the realm of the private (because the Canadian state is 'secular') and therefore, do not warrant intervention by the state. In this way, two seemingly contradictory phenomena occur simultaneously. On the one hand, food as multiculturalism reveals much about the relegation of economic grievances to matters of culture or individual politics. On the other, the state does intervene in commodifying this cosmopolitanism by turning ethnicized foods into a source of profit, which we return to in subsequent sections. In both instances however, a supposed multicultural power has cocooned economic and political power, thereby moving above the state as the former, and below it as the latter.

To summarize, food is important for the study of immigration because food nuances agency-oriented accounts in the sociology and political economy of food productionconsumption. Second, food is substantively significant in immigrants' daily lives, in their perceptions of the self and in the mediation of the settlement experience. Third, this same importance of food for cultural identity is also used as the basis of its appropriation, highlighting a class-based dynamic in production and consumption. To this end, state (non)interference in these spheres exposes the mobilization of political power when profits can be made.

Lastly, if it is true that in "every great philosopher there is the theme of direct participation of singularity in universality", (Badiou, 2006, p. 75) then food highlights our unity in the universal need to eat, the first of Maslow's hierarchy of needs. How then might food be reconceptualized such that its material bases are not lost in endlessly differentiated transnational 'signifying practices' or cultural singularities? 
The present analysis anchors itself in historical structuralism, an umbrella term which approaches the study of immigration through a Gramscian analysis, which draws largely from a Marxist foundation (Cohn, 2005). ${ }^{5}$ Although intellectually diverse, its unifying thread is an emphasis on the structural means of exploitation (within a historical context) or the ways in which one class dominates another (Cohn, 2005). As Theodore Cohn notes, "[in order] to understand capitalist domination, one must also be familiar with the political, ideological, and cultural aspects of class struggle" (2005:130). Thus, in interpreting the organization of society, politics and culture must be considered alongside economics because as Gramsci states, "every social form has its bomo economicus" (Gramsci as cited in Peet, 2003, p.15). Therefore, from this Gramscian-historical structuralist approach, it is inadequate to divorce the political and the cultural from the economic since every question concerned with economic growth is a question concerned with planned social change and by extension, necessarily a political question.

As such, I draw on select tenets of Marxist class analysis as expressed by political theorist Wendy Brown, historical materialist Robert Cox, and Slovenian philosopher Slavoj Zizek in part to measure the depth and breadth of their thought as applied to contemporary formations of power and in part because such abstract musings are one of the indulgences of academia. At first, I unpack the multiple symbolic and political elements of food to expose its power; only to recombine these constituent parts to create a new theoretical edifice which captures the complex linkages between ideologies, institutions, and material capabilities. With this recombinant view, the whole is greater than the sum of its parts.

\footnotetext{
${ }^{5}$ It must be noted that many of the aforementioned approaches diverge markedly from a purely Marxist analysis (Cohn, 2005).
} 
Furthermore, such a view of food, people and politics engages in a Hegelian 'picturethinking, weaving between theory and practice, ideology and impact, emotive significance and political consequence, while linking theoretical contours and sketches where necessary. Admittedly, an eclectic approach reflecting the proto-Nietzschean view that knowledge is fragmented, I employ these atomized conveniences of the mind, which capture slivers of social reality because I want to, like Kant exclaims, "Sapere Aude! [dare to know]. Have courage to use your own understanding!" (1784).

As my own concerns mirror those of Stuart Hall, I believe it is here that Robert Cox's (1987) insights enhance the analysis. Using historical-materialist ontology, Cox underscored the role of 'social forces' in the making of 'world orders'. ${ }^{6}$ Social forces, according to Cox, arise from the production process and are the main actors generated by the social relations of production (Cox, 1996).

In this analysis, I appropriate Cox's triptych of a 'historical structure' (consisting of ideologies $^{7}$, material capabilities and institutions) to explain permanency and selective mobility for people and things. I demonstrate that the braiding of commodity fetishism, multiculturalism and neoliberalism helps to explain the cacophony between intended and actual outcomes in immigration policy. These constitutive elements are seen as containing, as well as bearing the impact of, the others. This robust appreciation of the range of influences and actors affecting immigration provides justification for its use. Furthermore, in this formulation, state power ceases to be the sole explanatory factor and becomes part of what

\footnotetext{
"Social forces interact with the "forms of state", which arise from state/society complexes, and "world orders", which represent phases of stability and conflict, or the particular configurations of forces (Cox, 1996). 'In Cox's formulation he uses the term ideas, whereas I propose ideologies. As part of 'an initial dialogue' between the theorist and the particular world being studied, the semantic switch can be considered acceptable if one considers that changing realities necessitate the revision of concepts to accommodate advances in theory and knowledge (Cox, 1981, p. 87).
} 
is explained. Put another way, the model facilitates the interrogation of the very legitimacy of the state as a judge in who is a desirable immigrant.

Summarized briefly, a historical structure is a heuristic tool which traces the origins of linkages of power that circumscribe freedom and obscures substantive equality. In this model, ideologies, material capabilities and institutions configure in ways to impose pressures and constraints for who produces what. No one-way determinism is proposed; rather, their relationships are reciprocal. In my own formation, I substitute Cox's term of 'ideas/images' for a more comprehensive description of ideologies, advanced by Slovenian philosopher Slavoj Zizek (2000). To compare, for Cox ideas are shared notions of the nature of social relations which tend to perpetuate habits and expectations of behaviour. For example, an idea is a belief in the Westphalian ideal- that the people are organized and commanded by states which have authority over defined territories. As a compliment, images are collective, held by different groups of people. These are differing views as to the nature and legitimacy of prevailing power relations (Cox, 1981, p. 98-99). This distinction could also be read as thesis (ideas) and anti-thesis (images). Whereas the former are broadly common and constitute the terrain of social discourse the latter, formulated as alternatives or challenges to the former, are several and opposed. For Zizek, ideologies can be of three types: "in themselves", "for themselves", and "in and for themselves". Each of which will be discussed in subsequent sections. To my mind, Zizek's formulation of ideologies not only envelopes Cox's ideas/images schema but adds a third dimension by identifying the logic binding the two. This is his third element of "ideologies in and for themselves".

Lastly, institutions are the organizational instruments (via ministries, departments, policies or the state's functions) that perpetuate or stabilize a particular order. Institutions reflect power relations and can be understood as amalgams of ideologies and material 
capabilities that in turn, influence the development of ideas and material capabilities (Cox, 1981, p. 99).

Using the notion of an historical structure is a heuristic tool to study the governance of mobility in Canada, which offers a revelatory opportunity with respect to the central thesis advanced in this paper: the exploration of situations in which three main structures of power in Canada today interact which mirror global inequalities and reproduce them. They are: the global division of labour (material), the ineffable organizing principles (ideological), and power relations embodied in state apparatuses (institutions).

That one model alone cannot sufficiently account for all contradictory evidence in the explanation of a phenomena is obvious. Sophisticated theories, however, are able to transcend themselves when they have the ability or the potential to be reinvented in its new historical situation. It is my contention that Cox's model of a historical structure passes this test of appropriation, precisely because its theoretical architecture is based on the symbiosis of three interstices of power: ideological, material, and institutional. Furthermore, the model is particularly useful for its intervention in both production and consumption spheres, effectively moving beyond the debate that so plagues the food analysis in the sociology of agriculture (Goodman and DuPuis 2002). Together with similar intervention elasticity (statesociety) in the immigration literature, this construct bridges the two in a coherent way. Given that this analysis joins two disparate literatures, I focus exclusively on points of convergence between the two which produce normative, political, and material ordering principles for the governance of mobility. I start with ideologies.

\section{IDEOLOGIES: FENCES OF THEORY AND WINDOWS INTO PRACTICE}

"The ideologist is a man who falls for the fraud perpetrated on him by his own intellect: that an idea, i.e. the symbol of a momentarily perceived reality, can possess absolute reality" Socrates, refuting Plato's interpretation of his ideas 
"These changes are necessary to keep Canada's program competitive with that of other countries, and keep pace with the changing economy" -Immigration Minister Jason Kenney 2010.

Ideology: a generative matrix that regulates the relationship between visible and nonvisible, between imaginable and non-imaginable, as well as the changes in this relationship. (Zizek, 1994, p. 7).

By now, we know Francis Fukuyama's 'End of History' thesis which posited that the end of the Cold War also signaled the end of history: "that is, the end point of mankind's ideological evolution and the universalization of Western liberal democracy as the final form of human government" $(1989$, p.3). The closing chapters lament that:

the struggle for recognition, the willingness to risk one's life for a purely abstract goal, the worldwide ideological struggle that called forth daring, courage, imagination, and idealism, will be replaced by economic calculation, the endless solving of technical problems, environmental concerns, and the satisfaction of sophisticated consumer demands. (Fukuyama, 1992, p.18)

If we are indeed at the end of history and with the collapse of socialisms, what then is the place of ideology? Have we not evolved to a point of ideological mortis? This section makes the modest contribution that unlike Fukuyama's contention, we are not at the end of history and that ideologies still matter in explaining the inconsistencies of the intended and actual outcomes in state policy. To do so, I identify commodity fetishism as a latent ideology, which (de)valorizes immigrants in very precise ways and consistent with Canada's neoliberal posture. As such, this section illustrates the first claim that immigrants are increasingly viewed as commodities-their labour and cultural contributions are alwaysalready subsumed into an economic or political logic to bolster state legitimacy in administering policies of inequality. 
Ideologies are one of the three vectors proposed by Cox (1981) in his historical structure. Whereas Cox used images ${ }^{8}$ in his triangular model, I substitute Slovenian philosopher Slavoj Zizek's (2000) more comprehensive ideal types of ideology: as “ideology in itself", "ideology for itself", and "ideology in and for itself". As Zizek notes, "ideology is less about epistemology, more about power" (1994, p. $27 \mathrm{ff}$ ). Therefore, because this essay is concerned with the confluence of powers that govern mobility and shape life chances, an analysis of ideologies is critical.

Drawing from Zizek's (2000) ideal types, an "ideology in itself" is a complex of ideas (theories, doctrine, beliefs, argumentative procedures) intended to convince its subjects of its truth which concretely serves an unavowed power interest (p.10). Normally, these sets of ideas are represented by a dominant group which is then inculcated explicitly to the 'people'. The imperatives of 'globalization' are exemplary here. Based on an ideology of neoliberalism, the globalization project is ostensibly for the benefit of all which therefore requires collective cooperation and sacrifice. Similarly, an "ideology for itself" reflects ideology in its extemality, manifest in state institutions, to reproduce the relations of production using state apparatuses (state policies, ministries). An example of an 'ideology for itself would be the point system in the IRPA that reflects the ideologies of neoliberalism. Lastly, an ideology in and for itself is neither explicit doctrine nor its material form but a kind of elusive spontaneous ideology at work at the heart of society.

The commodification and subsequent devalorization of people under capitalism is an example of a seemingly elusive impulse. For this reason, this section aims to underpin the logic of commodity fetishism and neoliberalism which explain the movement of things over the movement of people.

${ }^{8}$ The move from images to ideologies was intentional. I wanted to avoid discussions of representation and discursivity. 
One of the most revelatory explanations for the erasure of food and those who produce it from the public consciousness is Marx's concept of alienation and commodity fetishism. Food, as if by magic, appears in bounty and beauty on supermarket shelves. The many tentacles that are involved in fertilizing, cultivating, manufacturing, packaging, marketing, retailing, shipping, are reduced to a store name. Such inability to name providence stems from the separation of the producer from the process. Summarized crudely, because labourers are alienated from their means of production under capitalism they have no recourse but to sell their labour power for wages. In order for generalized exchanged to take place, labour must be abstracted-in other words, qualitatively different forms of labour are transformed into homogenous, quantifiable units-therefore rendering the production process invisible. Indeed, "commodities draw a veil across their own origins: products appear and disappear before consumer's eyes as if by spontaneous generation, and it is an astute shopper indeed who has any idea at all about what most things are composed of or what kinds of people made them" (Jhally, 1990, p.49). Furthermore, as Marx explains, "the equalization of the most different kinds of labour can be the result only of an abstraction from their inequalities" (Marx as cited by Hudson \& Hudson 2003 p. 416). The result then, is for social relations between people to appear as social relations between things. For this reason, for Marx things do not carry values as an objective characteristic. Value is thus, a social relation "concealed beneath a material shell" (Marx 1867 as cited by Hudson \& Hudson 2003 p.415). Interestingly, Canadian citizenship is also a fetishized commodity on the part of potential migrants signaling the promise of multiculturalism, economic stability, and integration but obscured is the colonization, and subsequent economic and political relations of subordination that have historically combined to produce this status. 
This commodification is exacerbated by global capitalism as workers become subsumed into a global labour market. Such a climate facilitates the encroachment of a consumer/provider transaction on every type of social relation (Gilbert 2008). Because work has trumped over all other ways of existing (Gorz, 1991), it follows then that an individual's 'value' or 'net worth' to Canada is determined by their work. Or, the simple summation of skills and their capacity to contribute to the economy based on their expected place within it (Arat-Koc, 1999, p. 36). In fact, commodification is virtually legislated through the immigration point system which hand-selects 'the best and the brightest'. If people are viewed as aggregates of their skills, it is women and other always-already exploited groups that bear the brunt of this calculation. This is because skills are not neutral evaluations of competency, but ideologically based on the sexual and international division of labour (Gabriel, 2004, p.164). To illustrate, because women's unpaid work in social reproduction occurs in the home, it is left unrecognized since such skills do not produce an ultimate exchange value under neoliberalism (Cheng, 1999, p. 48).

In the context of food production, much of the literature that examines recent changes in women's work in agriculture links women's increased participation in agricultural work to the neo-liberal policies enacted by many countries of the Global South since the early 1980s (Lastarria-Cornhiel, 2006). Fiscal stabilization policies sought to correct balance of payments problems, reduce inflation rates, and increase exports. The accompanying stabilization and structural adjustment policies included import liberalization, privatization of government sector resources and services, and liberalizing labour, land, and capital markets. The effects of which are historically specific and unique to neoliberalism. 
These are: a change of the type of export agriculture practiced (high-value agricultural exports have replaced traditional lower-value exports), the type of wage labor demanded by commercial agriculture (a seasonal and temporary labour force rather than permanent labour force), and the viability of smallholder agriculture since export-oriented agriculture has undermined and/or replaced subsistence agriculture (Lastarria- Cornhiel, 2006). According to Lastarria-Cornhiel (2006), in general terms, export agriculture in developing countries has shifted from traditional export crops grown on plantations such as coffee, sugar, and cocoa to labour-intensive horticulture crops such as vegetables, fruits, and flowers.

And it is women in the developing world that have responded to such changes. By broadening and deepening their involvement in agricultural production over the last few decades, women increasingly shoulder the responsibility for household survival and respond to economic opportunities in commercial agriculture. This trend has been called the feminization of agriculture (Lastarria- Cornhiel, 2006). Studies from various countries in Latin America confirm that the increase in vegetable, fruit, and flower agti-businesses have seen concomitant growth of women in the proportion to the labor force. For example, in the fruit production of Chile's central valley, women made up over 50 percent of the temporary workers (Bee 2003 as cited by Lastarria-Corhiel, 2006). In Sinaloa, Mexico women comprised 40 percent of the field workers and 90 percent of the packinghouse workers by the early 1990 s in the vegetable industry, (Lara Flores $1992 \& 1995$ as cited by LastarriaComhiel, 2006). And in the flower industry in Colombia and Mexico, women comprise between 60 to 80 percent of the workers (Dolan and Sorby 2003 as cited by LastarriaCornhiel, 2006). These studies also revealed that the small proportion of permanent jobs in these industries is overwhelmingly held by men. 
Much like in Latin America, economic liberalization policies have increased women's agricultural participation in sub-Saharan Africa. As evidence, multicountry, multicrop studies found that women comprised between 53 and 85 percent of persons employed in high-value agricultural export production such as flowers, fruit, and vegetables (Dohan 2005 as cited by Lastarria-Cornhiel, 2006). In Kenya's fruit and vegetable exports, for example, women work in the field and in processing and packing plants. By the late 1990s, they comprised between 70 and 80 percent of workers in certain tasks such as packing, labeling, and bar-coding of produce. Horticultural export firms prefer young, single women who were seen as appropriate for this type of work and flexible in their willingness to work at many tasks and without security of employment. Many of these women are also migrants (Dolan 2005: 1718).

Such evidence points to two trends in agricultural changes under neoliberalism, First, the need for flexible labour and second, the shift to high-value agricultural exports. The two are concordant since the dramatic growth of high-value agricultural exports, dominated by agribusiness and export firms, has dramatically changed the agricultural labor force. Where formerly plantations hired a largely permanent and male labour force supplemented by temporary male and female labour for the peak harvest period, agri-business and agricultural export firms now hire mostly temporary labour with a small cadre of permanent workers (Lastarria-Cornhiel, 2006).

These tendencies are also echoed in Canada with our own Seasonal Agricultural Worker's Program. While much has been done to document the 'unfree' labour of Mexican and Caribbean men under the Canadian Seasonal Agricultural Workers Programme (CSAWP), women and a gender analysis have remained largely on the margins of the sociology of agriculture (Allen and Sachs 2005). Preibisch and Hermosa Santamaria (2006) 
confirm that "although this literature has brought to the light the previously unstudied phenomenon of the foreign agricultural workers, both women and a gender perspective are missing (p. 109). In Canada, Mexican women for the past 30 years, since their inclusion in the CSAWP, have been employed to pick and pack fruits and vegetables, plant and care for ornamental and nursery plants, select wine grapes, or food processing and canning. As Prebisch and Hermosa Santamaria (2006) explain, "employers choose their workers and allocate tasks accordingly to gender ideologies of men and women's ability to perform agricultural work" (p. 118). Citing a 'finer, lighter touch', greater patience and efficiency, the Department of Labour in Mexico identifies women as particularly well-suited for tasks dependent on delicacy and dexterity (Preibisch and Hermosa Santamaria 2006). In this way, gendered ideologies of who is best suited to which tasks dictates the sexual division of labour between Mexican men and women. While both men and women face multiple oppressions under the CSAWP, women's precarious status is further compromised by patriarchal legislation and practices that shape who migtates, under what conditions, and their work once in Canada.

Eligibility under the CSAWP hinges on proof that men and women are economically destitute and lacking in assets such as education and land. Tellingly, these requirements are "precisely the inverse of the qualities needed to qualify for immigrant status" (Preibisch and Hermosa Santamaria, 2006, p. 112), which gives permanency to the products-agricultural commodities, while denying producers permanency in the country. Unlike their male counterparts however, who among Mexican women is allowed to migrate differs markedly.

Not only does the sexual division of labour shape and organize migration, Mexican women's citizenship status as temporary migrant workers, denies them the services, protection, and labour market privileges afforded to the host citizenry. This denial of basic 
freedoms in the labour market (such as the freedom to choose one's employer, to live away from the job site, to change employers, or have unionized representation) is an example of Bauder's (2008) conceptualization of citizenship as a form of strategic capital. In this view, citizenship produces processes of inclusion and exclusion in economic and social domains. It is created, conferred, and denied to reproduce privileges in the labour market to the host citizenry. Given that "industrialized economies have become structurally dependent on the availability and continual supply of migrants labour" (Bauder, 2008, p. 316), it follows then that methods of distinction and reproduction are necessary to maintain their vulnerability and consequent exploitation. In this way, the passport functions as a password, granting access to and privilege within the labour market. In sum, Mexican women's precarious status allows labour-importing countries such as Canada to dictate and direct to a greater extent, the conditions under which foreign workers enter the country, labour within it, and eventually leave (Preibisch \& Hermosa Santamaria 2006).

From these examples, we see that the importation of labour is heavily influenced by existing gender hierarchies and prejudices in both labour receiving and labour-sending countries. We also see that the gendered aspect of citizenship (marital status), strategic conferral and denial of citizenship (on the part of the Canadian government), exclude women from participating fully in social and economic life by bounding them in 'unfree' labour chains in the production process. The free movement in the labour market is reserved for citizens or permanent residents, which systematically and cyclically recycles foreign workers into gendered migration schemes.

By masking asymmetries of social relations, commodity fetishism provides a direct response to why people are selectively mobile and why food commodities can flow without restriction. As physical and social distance increases, the eating experience mediated by the 
grocery store allows us to consume without knowing. This is Marx's dictums of ideology and of alienation, "they do not know it, but they are doing it", which highlight the power of ideology to produce real outcomes. We can in practice consume a meal "without the slightest knowledge of the intricate geography of production and the myriad social relations embedded in the system that puts it on our table... we cannot see the fingerprints of exploitation upon them"... (Harvey 1990, p. 422-3). In Ontario, the "fingerprints of exploitation' on what is 'locally grown' belong to the foreign workers from the Caribbean and Mexico employed with the CSAWP (Preibisch and Hermoso Santamaria 2006, Basok 2003, Barndt 2007). The Canadian agriculture sector is structurally dependent on the availability and continual supply of migrant labour (Bauder 2008, p.316). This is because the Canadian-born have used their labour market privilege to avoid the danger, dirt, and difficulty of agricultural work. In contrast, seasonal agricultural workers essentially become mobile labour units under this schema, providing evidence of Canada's use of noncitizenship to condition "unfree" labour (Bauder 2006, p. 26). Thus, the temporary worker is the figure of the worker who is no longer a worker, who no longer has a trade but only abilities that he or she can sell where she can and whose very ability is also a kind of worth. In this sense the worker becomes a commodity, freely displaced, and impermanent.

\section{Food as Culturat. Currency: Buxing aNd SEttling for ReCognition}

Interestingly, established immigrants have the 'privilege' of a commodification of a different sort. If they themselves are not commodified, their ascribed cultural identities are. This commodification comes in the form of food, for its close association with culture (Barthes, 1961). The diverse foodscapes in Toronto for example, are seen as the totemic proofs of the multicultural ideal. The simplistic addition of various foods hides systemic power imbalances in production and labour policies, described above, which further 
reproduce inequality. Indeed, this richness in plurality sustains the myth of Canada's unity in diversity.

While it is true Canada is ethnically, linguistically, and religiously diverse, it is not true that it is unified, as democratic racism and race-based economic disparity point out (Teelucksingh and Galabuzi 2007). Commodification in the context of shallow multiculturalism further exacerbates the evaluation of immigrant participation based exclusively on easily identifiable contributions. 'Ethnicized' foods are one such contribution. Relying on essentialist notions of culture, seemingly positive depictions of 'ethnic' foods as more sophisticated, elaborated and flavourful than fast food or 'Canadian cuisine' engages an ideology that cultural encounters result in "a new delight, more intense, more satisfying than normal ways of doing and feeling" (hooks, 1992, p. 179). Understood here is that 'white' is not considered 'ethnic' or a culture rather it is the normative standatd; such is the nature of 'white privilege'. Thus, exotic encounters in the form of food further reify shallow multiculturalism by displacing the historically and politically constituted power relations that mark their interaction. As Homi Bhabha explains,

Although there is always an entertainment and encouragement of cultural diversity, there's always a corresponding containment of it. A transparent norm is constituted, a norm given by the host society or dominant culture, which says that these other cultures are fine, but we must be able to locate them within our own grid $(1994$, p. 72$)$.

Understood in this way, multiculturalism is always posited as conditional. The caveat is, "Immigrants are fine as long as..." In the case of food, they are great when their cultures can be extracted through food while keeping other, social boundaries intact. This paradoxical social proximation on one hand, yet distanciation on the other, can be described as a 'safe multiculturalism' that requires no further reconciliation between the dominant and dominated groups (Saloojee, 2003). 
Therefore, the tying of immigrants to their food is related to the commodification of culture made possible under neoliberalism. In neo-liberal logic, food acts as cultural currency, to be traded and exchanged in order to purchase recognition. This is also the idea of cultural capital (Bourdieu as cited by Bauder 2008). That is, because immigrant's cultural contributions only become visible once recognized for their market value, they must be sold on the market. The commodification of such contributions can only be fully understood in the context of a multiculturalism project which is willing to incorporate immigrants only to the extent that they conform to its needs (as agricultural workers, domestic workers, providers and preparers of ethnic foodstuffs), and through this process reproduce the labour force through the most basic of social reproduction—food. Multiculturalism when coupled with neoliberalism is systemically ruthless in its exclusion of those least equipped or willing to abandon practices for which neoliberalism has no use (Gillbert 2008). The result is the entrenchment of racial hierarchies (Duffy 2007).

The moral reprisals and the economic sanctions of such a utilitarian vision of the self through work are obvious and need not be elaborated here, but it is precisely the fact that such cost-benefit analysis of immigrants, exclusively as workers, are accepted as 'common sense' or 'necessary' that they are important. The rationalization of evaluating people in this way points to the pervasiveness of ideology in producing concrete life conditions-in citizenship, occupation, economic sustenance, and social inclusion-for newcomers to Canada.

To conclude, the commodification of immigrants through their labour and culture follows a perfect neoliberal project of capital accumulation. If food is understood as a type of culture capital necessary for the multiculturalism project, which the Canadian state uses as proof of unity in diversity, and labour is understood as necessary for the accumulation of 
real capital, then both are actively solicited by the Canadian government. The result is a further entrenchment of always-already existing gender and racial inequalities globally, which are then reproduced in Canada and exacerbated through neoliberal restructuring, raising questions as to whether the liberal ideal of equality is possible under capitalism. In other words, if 'aberrations' of the system (i.e. hunger, environmental degradation, racism, sexism, ableism, and other mechanisms of stratification) are not malfunctionings rather, structurally embedded and necessary to the functioning of the capitalist system. Such political suppression and 'mismanagement' of social ills reflects the ill-fate of the Canadian multicultural project, which subverts the project for substantive equality, explained below.

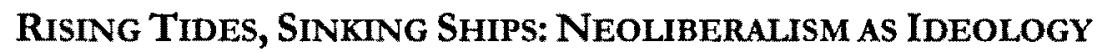

If we know the malaises of a multicultural immigration project: from the emphasis on difference and the obfuscation of power relations, from the racialized and gendered division of labour, from the state disavowal of immigrants upon arrival ${ }^{9}$, how is it that these phenomena can persist without a substantive challenge to state power? This is the stealth power of ideology to blur the lines of who is accountable or what is responsible. Globalization is often the buzzword employed by politicians to justify economic or immigration reforms. But the term 'globalization', rather than being a catch-all adjective or noun describing a process or the character of the current economic world order, tefers to a specific and clearly defined ideological orientation-neoliberalism (Oguz, 2005). Globalization, despite its purported benevolence masks neoliberalism which "was from the very beginning a project to achieve the restoration of class power" (Harvey, 2000, p. 16).

\footnotetext{
${ }^{9}$ This is not to suggest that the Canadian state completely abandons immigrants upon arrival. Rather it is to emphasize its 'shadow state' and the need for NGOs and settlement agencies to create parallel service structures while engaging in a cliental relationship with the government (Karim, 2004, p.5).
} 
In this sense, it is illustrative of Zizek's 'ideology in and for itself". As such, globalization qua neoliberalism is a systematically distorted communication-a text-in which there is a gap between its 'official' public meaning from its actual intention. According to David Harvey (2000) neoliberalism holds that individual freedom and liberty can best be upheld by strong property rights, free markets, and free trade. The concessions of privatization, liberalization, internationalization of production, and the 'rule of the market' are seen as necessary and sufficient to increase global output hence prosperity for all. Such is the idea of the globalization rising tide, lifting precarious lifeboats. Obviously, the tide is not rising equally for everyone rather, some drown while others watch patronizingly with secure life jackets.

To ensure the accumulation of capital, the role of the state is to provide amenable conditions for free enterprise to flourish, which entails protecting the right to private property, providing business incentives, widening and deepening the market mechanism, and flexibility so that labour moves freely in order not to impede profit (Harvey, 2000). Murray (1971) offered a seminal contribution to this discussion by demonstrating that as capital expands territorially, it faces the problem of ensuring liberal state economic functions such as guaranteeing property rights, standardizing currency, access to land, organizing the macroeconomic structure of the economy, and providing the ideological conditions of production and trade (as cited by Panitch, 1994, p. 65). Put another way, the accumulative functions of the state run counter to its legitimizing functions, which require some measure of state autonomy from exclusively business or corporate interests. The reparative functions of the state then exist to buttress these conflicting interests. That is, the global inequalities mirrored and reproduced within the Canadian state through its neoliberal policies suggests first that, Canada's role is not merely litigator. Instead, through aggressive immigration and 
agricultural policies, it is clear that Canada actively pursues its neoliberal promises at the expense of its stated commitments to multiculturalism and equality.

To buffer this disjuncture between official thetoric and actual experience, multiculturalism as food becomes the exotic nexus from which grievances of inequality and access to power are articulated as cultural issues. To clarify, when multiculturalism is framed as cultural antagonism and with the dual slippages of culture qua identity and accommodation qua integration, it ellipses the fact that identity cannot 'legitimately' be articulated in other forms such as class in the liberal democratic state. This is because the liberal democratic state is divided into the state, economy, and civil society. Culture, understood liberally as language, religion, shared customs, rituals, and worldviews are outside the sphere of formal politics given supposed state secularity. In this way, it is the suspension of other identities that multiculturalism hides. Indeed, it is "liberalism's conceit about the universality of its basic principles: secularism, the rule of law, equal rights, moral autonomy, and individual liberty. If these principles are universal then they are not matters of culture, which is identified as the particular, local" (Brown, 2006, p.152). In short, the failures of multiculturalism qua integration denies seeing the state as critical vehicle, effect, and importantly, legitimate administrators of power.

Such a view of the state is fundamental in a critical analysis of state functions and legitimacy in the context of the globalization project which discursively withers state power and autonomy. Indeed, the globalization of capital directly implicates the state because it refers to broader questions of who or what will undertake the public functions necessary for the reproduction of the capital accumulation process (Oguz, 2005). These aforementioned public functions cannot be analyzed separately from the political and ideological conditions from which they are produced (Oguz, 2005). 
The 'favourable conditions' required for investment and capital attraction necessitate a lean neo-liberal state that downloads previous social spending to the individual (Arat-Koc 1999). Neoliberalism posits the market, depicted ideologically as the great means to foster competition and innovation, as the great equalizer of conditions that allows for wide-ranging freedoms of both contract and exchange, "what this language hides, though, is that the terrain of the market isn't so much a playing-field as a razor's edge" (Patel, 2007, p.7). The neoliberal ethos thus can be summarized as privatization, deregulation, internationalization of production, and the 'rule of the market' within the context of a state whose citizens must be self-reliant. Their own efficiency is necessary so that the state can focus on establishing the conditions for profitable accumulation, later to redistribute wealth to the least of these 'citizens'.

Although an ideal-type model of neoliberalism, it is important to sketch its definitional contours before proceeding to subsequent chapters which problematize neoliberal ideology in action in the Canadian context - especially as it relates to the relatively easy mobility of food as a commodity and not of labour. Insofar as ideologies define the parameters of what can be thought, said and experienced it remains critical for the pursuit of democracy as a way of constituting and thus distributing political power while denying the possibilities of substantive equality.

\section{THE ILL-LIBERTY OF INSTITUTIONS: CANADA'S IMMIGRATION SYSTEM AND THE MULTICULTURAL EMOLLIENT OF DIVERSITY}

Liberal institutions cease to be liberal as soon as they are attained: later on, there are no worse and no more thorough injurers of freedom than liberal institutions. Their effects are known well enougb; they undermine the will to power... they make men small, cowardly, and bedonistic. 
As we have seen, the globalization project sharpens the divide between the legitimizing and accumulative functions of the neoliberal state. As such, I begin with a naive but important question: what mechanisms are 'legitimately' available to the state to control the permanency of people? These mechanisms are its institutions. The emphasis here is the point system codified in the Immigration and Refugee Protection Act (IRPA).

Institutions are the second constituent vector of Cox's historical structure. In his view, institutions are the organizational instruments (ministries, departments, policies, etc) that perpetuate or stabilize a particular order. While institutions are not equated to policies, the former ensures the effective implementation of the latter. They reflect power relations which are the amalgams of ideologies and material capabilities, and in turn these institutions influence the development of ideas and material capabilities (Cox, 1981, p. 99). For this reason, it is untenable to discuss state institutions without their accompanying ideologies. For Zizek (2000) institutions can be described as 'ideologies for itself. That is, ideology in its externality, manifest in state institutions, to reproduce the relations of production. It was Louis Althusser who described Ideological State Apparatuses which point to the material existence of ideology in practices, rituals, and institutions (in Zizek 2000, p.120). For Althusser, these apparatuses are multiple, 'relatively autonomous' and increasingly indifferent to their own consistency but always reflecting the ideology of the dominant class (Zizek, 2000 , p. 114). In this view, globalization ideology is putatively corroding state power.

In its multiple snapshots of 'globalization', we see two images; one in which the state is increasingly ceding sovereignty to powers above itself (transnational governance structures and transnational corporate power), the other, a hollowed state from below (from grassroots mobilization). These images are not contradictory. Although it appears that the state is increasingly indifferent in a 'post-Westphalian' order, it is exactly these discursive ellipses and 
'eventualities' that must be analyzed, which is why this section asks about state transformations, restructuring, and relevance with and for the advancement of global capitalism and not because of it. An analysis of institutions scrutinizes state activities as condensations of relations of power (Brown, 1995, p.16).

Through an examination of Canadian immigration institutions and their accompanying state policies, norms, and standards, namely the ascription of status via the point system, I argue that global inequalities are mirrored and reproduced on a national scale, lending to further exploitation in the global labour market. To return to the problemmatique announced at the outset of this paper, the assignment of status partially responds to who can stay or why some are permanent. A look at the neoliberal dynamics of Canada responding to 'external pressures', provides insights on what is permitted to move and on what conditions.

As a secondary analysis, this section challenges the compartmentalization of the spheres of production and consumption on regional, national, and global scales. It demonstrates the interconnectedness of agricultural and immigration policies drawn up in Canada and implemented abroad. As such, I examine the impacts of immigration on the food production-consumption cycle, which fuels the Canadian economy by skewing food production patterns globally that in turn, reifies the hyper mobility of commodities over people. Taken together, I argue that food becomes the exotic nexus justifying multiculturalism as public policy as opposed to a more substantive focus on constituting power and distributing it. In this case, the choice of what to consume becomes a stand-in for a real democratic ideal-in which, humans might govern themselves by governing together (Brown, 1995, p.5). The result of such a form of consumptive democracy is a lack of interrogation of the multicultural ideal and stunted efforts to democratise democracy.

\section{Conditional Permanency, Permanent condrtionality: Immigrant Status} AND LABOUR 
Immigration policy, as expected to "result in the greatest possible economic and social benefits for Canada" (CIC, 2002a) is then unequivocally an explicit part of Canada's economic policy (Arat-Koc, 1999, p.32). It responds directly to labour market needs. This economic imperative is not to be overlooked despite being accompanied by humanitarian and reunification sympathies. Doing so, obscures state power as currently the only 'legitimate' form of political organization that secures the ideological and political conditions necessary for reproducing capital accumulation and its attendant restrictions or liberties on mobility (Oguz, 2005, p.3). This obfuscation is the first of liberal state powers in reifying the legitimacy of the tripartite state order: state, economy, society, in which the economy is understood as natural. For this reason, we speak of political intervention in the economy to describe economic policy, as if politics were external to the market (Brown, 1995, p. 145). When such splintering occurs, both the market and the government become unaccountable to their aberrant consequences.

Thus, given that immigration and economic policy are intimately intertwined, institutions are the outward expressions of their agreement. Therefore, if institutions matter in the functioning and reproduction of labour markets, "then labour markets matter, for this is the scale in which labour is mobilized and produced" (Stasiulis, 2008, p. 111).

As an immigrant-receiving country, the type of status (family class, refugee, economic class) granted to migrants is a direct reflection of their place within the global hierarchy of labour and capital. To illustrate more concretely, the IRPA places a high value on 'human capital': transferable skills over many professional domains, linguistic competency in English or French, education, adaptability, job related experience. Such are the demands for 'success' and competitiveness in the new global knowledge economy (Moore 2001). For women, given that under the point system unpaid work is not recognized and in the hopes 
of maximizing the possibility of entry to Canada, women often enter as family class applicants who are then systemically denied access to critical language training and daycare programs that have proven indispensable to insertion in the labour market (Arat-Koc 1999). In this way we see that commodification intertwined with classed and gendered systems of subjugation compound immigrants' depressed economic and identarian status.

For migrants of the Global South, class is an important determinant of access to education. Those who occupy a privileged position in the class structure of their home country can nominally enter Canada as economic class migrants. Such access to education can also translate into cultural capital, or an understanding of place-specific norms, cultural codes or conventions (Bauder, 2008, p. 324). These 'soft skills' like team-work, leadership, and intergroup communication competencies ate often the subtle mechanisms of exclusion or discrimination in Canadian workplaces (Bauder, 2008, p. 324).

In contrast, those without access to education in their home countries must turn to entrance to Canada under temporary work schemas, which further entrench their economically marginalized position. In this way, Canada profits from global inequality by capitalizing on the asymmetrical access to education in countries 'structurally-adjusted' to remain competitive. The resultant alignment of class status of migrants in their country or origin with their immigration status in Canada compounds class based power labour markets domestically and internationally. Objections arise: If the former were true, foreign trained doctors and engineers would not be prevented from practising in Canada. If the former were true, why then are recent cohorts of immigrants, despite being more highly educated with similar command of either English or French as previous cohorts, performing worse economically than their historic counterparts (Reitz, 2005, p. 5)? 
The disjuncture can be explained by the real existence of "two labour markets in Canada —one that is Canadian and another that is foreign—with their different entitlements and rights", despite being masked as a singular and non-discriminatory marketplace (Sharma, 2006, p. 107). The inherent bifurcated labour market exposes the flimsy starting premise of human capital theories 'ceteris paribus', and rely on the 'invisible hand' to regulate with the cooperation of the Canadian state to 'mediate'.

Again, this duality raises cautions against the legitimacy of the state, economy distinction in liberal democratic regimes like Canada. For this reason, while class facilitates permanent status for the economic class, upon arrival the Canadian government can and does relinquish responsibility for the conditions of their settlement for two reasons. Firstly, in order to safeguard the legitimacy of state sponsored immigrant-importation, the government must assuage national constituencies, the Canadian-born of the perceived threat or competition that this labour force presents for 'scarce' jobs. Second, such relinquished responsibility on the conditions of settlement is permissible by the government given their selection of 'self-sufficient' immigrants who are to expected to 'hit the ground running' (Arat-Koc, 1999, p.34). Following this line of logic then, good immigrants are those that, "recognize the limits and liabilities of state provision and embraces her obligation to work longer and harder in order to become more self-reliant" (Brodie 1996 as cited in Arat-Koc, 1999, p. 34). Thus, while the Canadian-born can rely on the state to uphold their birth-place based entitlements, the foreign born are not afforded such a luxury despite committing to the same equal treatment, through citizenship, as their Canadian-born counterparts.

Subtle but pervasive mechanisms of discrimination/exclusion within regulated professions further prevent immigrants from penetrating certain sectors of the national labour market, reserved for the Canadian-born (Girard \& Bauder, 2007). The result is a 
reproduction of the social division of labour in which immigrants are colour-casted in specific segments of the economy. Not surprisingly, food retail, production and preparation are some of these sectors (Drummond and Fong, 2010).

Here we confront an interesting paradox. On the one hand, immigtants in Canada are systemically barred from penetrating select segments of national labour markets which reproduces domestic inequality. On the other, immigrant food consumption relying on home-country foodstuffs, necessarily means participation in international commodity markets, which reproduces global structures of trade inequality and asymmetrical recourse to dispute mechanisms offered by the World Trade Organization. With a projected $22 \%$ percent of the whole Canadian population as visible immigrants by 2017 and one-in-four foreign born, it is anticipated that changes to foodscapes will also accompany this demographic shift (AAC, Long Range Consumer Outlook 2005). In the competitive Toronto food industry, the rise in ethnic food processors correlates to new niche and general markets (AAC 2008). Restaurants are increasingly marketing to conspicuous consumers with aspirations of distinction in the consumption of 'ethnicized food'. Indeed as an Agriculture and Agrifood Analysis (2008) on the ethnic food sector in Ontario confirms, "results show

that 'authenticity of taste' and the promise of that authenticity in the marketing of such foods are key" (p. 3, emphasis mine). The suggestion of authenticity which recognizes an essentialized exoticization of culture thus exacerbates and perpetuates cultural commodification while reproducing systemic inequalities.

In addition, where climate and structural conditions dictate otherwise, Canada has mitigated loss to its market share by redirecting efforts in the value-added stages of packaging or in the export of certain food categories to the ethnic market in the United States (AAC, 2008, p. 12). Interestingly, the large Chinese, Indian, and South Asian 
populations in South-western Ontario who are 'ethnically matched' to corresponding groups in the north-eastern United States are seen to provide, "a strong position from which to promote the authenticity of products produced in the Province [Ontario]" (AAC 2008, p. 13). This is exemplary of Canada making itself in its own image. By exporting foodstuffs produced in Canada, whether or not they are produced by the ethnic groups themselves, this semblance of authenticity is used to exclusively to bolster retail value. An analysis of this exact commercialized authenticity is chronicled by Elliot (2008) in her analysis of packaged representations of 'foreignness' in the President's Choice "Memories Of" product line. She reveals that despite the tropes and allusions to faraway lands, weathered faces, and traditional means of production in reality the products are all made in Canada as Canadianized interpretations of ethnicized foodstuffs.

The Canadian government as well as select agribusinesses and food retail chains are well-attuned to the profitable business potential that exist for consumers of ethnic foods. Recognizing reliance on export markets, a Strengths, Weaknesses, Opportunities, and Threats report on the ethnic food industry intended to assess "whether import substitution opportunities exist to replace imported ethnic foods" (AAC 2008, p.3). They note that the convergence of demand with supply is 'always essential' for “.... an ever-increasing demand and an ever deeper penetration into the mainstream marketplace" (p.3).

What is crucial to note here is that while previous agricultural policies opened up agricultural economies of the Global South to export-oriented production, in a protectionist reversal, these exports are becoming superfluous as Canada seeks new ways to produce domestically. In this way, we see recurring patterns of production and consumption inequality that privilege the material capabilities and technology of the Global North, that can more easily be substituted over capital-poor agricultural economies of the Global South. 
The combined asymmetrical positioning of the Global North and South in a global capitalist economy precipitated a food crisis characterized by abrupt and severe increases in food prices which considerably extended the proportion of the world's population suffering from hunger in 2007-2008 (van der Ploeg, 2010). The crisis however was not just the sum of a series of triggers including: speculation, extremely low levels of world grain reserves (actively run down as part of the neoliberal project), extreme weather conditions in major grain producing countries and the impact of biofuels (van der Ploeg, 2010). Instead, it could be understood as symptomatic of the combined effects of neoliberalism in crisis. As food sociologist Phillip McMichael has elucidated, "this food 'crisis' represents the magnification of a long-term crisis of social reproduction stemming from colonialism, and was triggered by neoliberal capitalist development" (2009, p. 1). Such are the cruxes of the following chapter.

\section{Material Capabilities: Profitable and Powerful Food}

The world eludes us because it becomes itself again- Lewis Carroll

Returning again to Cox (1981), material capabilities are productive and destructive potentials. In their dynamic form they exist as technological and organizational capabilities, and in their accumulated forms as natural resources which technology can transform, stocks of equipment, and the wealth which can command these (p. 98). This section looks at the neoliberal dynamics of Canada's agricultural sector responding to 'external pressures' which provides insight on what is moving and on what conditions. Building on previous arguments, I argue that while global capitalism has turned people into commodities by commodifying their labour; it has also turned back on itself. To clarify, I demonstrate that in agriculture, global capitalism is making a full circle as neo-colonial relations serve as remedy 
for colonial illnesses and in a dizzying tautology, the disease has become the cure ${ }^{10}$. This final section argues that by simultaneously bowing to and ushering forward neoliberal dictates, the legitimacy of Canada's sovereignty is compromised and its multicultural mirage exposed.

As the previous chapter highlighted, "the history of agriculture in developed countries over the past seventy years is first and foremost a political history because of the intense interplay between farming and the state" (Morgan et al., 2006, p. 26). This is especially true of Canada as its immigration policy initially set to recruit farmers able to establish Canada as a British-settler colony (Kelley and Trebilcock, 1999). Agricultural and political regulation were intimately linked to the processes of colonization that led to the creation of a settler colonial state; in which land and other resources of the First Peoples were forcibly appropriated. This appropriation is at the heart of shallow multicultural policies as emollient balms to soothe the colonial conscious. Indeed, the incessant necessity 'to define 'Canadianness' rests on the primary exclusion of the Aboriginal nations.

The twinning of agricultural and immigration policies highlights that agriculture is not an isolated industry, unaffected by outside pressures. Indeed, the structure, mores and prescriptions of neoliberalism reflect the nature of embedded power as production in agricultural policy. It is however unique for at least two reasons. First, when compared to industry, the means of production can be multiplied whereas in agriculture land is a fixed resource (Buttel 1980, p.90). Second, the rationale for its exceptional status might vary from country to country, but invariably has something to do with this distinguishing feature: we ingest its products (Morgan et al., 2006, p. 26). Just as Canada's immigration policy is influenced by the neoliberal dictates of both national capitalism and global capitalism, so too

${ }^{10}$ In this case, the disease refers to the need to follow an export-oriented agricultural schemas because of falling terms of trade for subsistence agricultural commodities. 
has Canada's agricultural policy been restructured to accommodate a (created) climate of scarcity, competition and efficiency.

To begin, I highlight the points of convergence between Canada's immigration and agricultural policies, which facilitate the free movement of some people and things while simultaneously denying that mobility to others considered burdensome on the Canadian state. On June $29^{\text {th }}, 2007$, ministers of agriculture from across Canada articulated a 'new vision' for Canada's agriculture initially: "An industry that is innovative in seizing evolving market demands for food and non-food products and services within an environment that fosters prosperity and opportunity for the entire value chain, creating benefits for all Canadians (Agriculture and Agrifood Canada 2006)". Later it was reformulated to, "a vision of a profitable and innovative industry that seizes opportunities in responding to market demands and contributes to the health and well-being of Canadians" (Agriculture and Agrifood Canada 2007, p.6). With a view to building a competitive and innovative sector, being proactive in managing risks, and ensuring the sector contributes to society's priorities, the vision included as expected all of the signposts of neoliberal 'rationality'. Interestingly in the second formulation food is omitted entirely, which points to two shifts. First, food is no longer recognized as distinct from other industries in the sense that human survival is premised upon it and second, contingent on the first, that it will be treated as every other industry irrespective of the agreements Canada has signed to the universal right to food (Rideout et al., 2007). In the above locution, 'Canadians', like in immigration policy, are understood with a number of qualifiers: the taxpaying Canadian, the formalized citizen, the 'deserving immigtant', the economically contributing 'stakeholder'.

The depth and breadth of the ideology of neoliberalism has been pervasive in the agricultural industry. Because international migration is a way for states to access the global 
labour market, states must at once, discipline this labour and selectively free it to access global capital (Overbeek 2002, p. 13). For this reason, regulating migration under the auspices of global neo-liberalism on the one hand and upholding the values of democratic governance on the other, become antagonistic. While Overbeek (2002) calls the disciplining of this labour the 'downward harmonisation' (p.13), it can also be characterized as an arms race for talent. Talent, in this sense, is not limited to the high skilled. Each country building up their stockpile of both light and heavy armament in turn provokes other countries to follow suit. This is the neoliberal logic of competition.

A second tenet of neoliberal orthodoxy is market expansion. In Canada, national food production outstrips domestic consumption for certain goods. Thus, following its dictates, the agricultural sector continually seeks new recipients of its over-production given that "access to global markets is critical to the functioning of the [agricultural] sector" (AAC 2006 , p. 3). Much in the same way, access to reservoirs of exploitable labour in 'global markets' in the Global South, is structurally necessary for the Canadian economy under global capitalism. Working through the World Trade Organization, the export-oriented sector has allowed farmers to increase production despite the fact that real commodity prices have decreased. In fact, currently Canada is 'an agriculturally export dependent nation' with $40 \%$ of its production exported, an increase from 32\% in 1986-1990 (AAC, 2006, p.3). For ethnic foodstuffs however, Canada is a net importer.

Similarly, for a lean and efficient state, enterprises must be consolidated such that inefficient firms can be subsumed into larger, more productive enterprises. The Darwinian survival of the fittest has also impacted Canada domestically. So intense is the pursuit for productivity growth, the real value of production has tripled over the last 45 years while the number of farms has been halved (AAC, 2006, p.3). Those that have survived, in the last 10 
years, close to one third of farm families experienced chronic negative net income (AAC 2006, p.7).

In Canada, food retailing has also seen an increase in consolidation and concentration. The number of food retail stores declined from 33, 000 (in 1990) to 24000 (in 2004), while the average sales per store more than doubled over the same period. Tellingly, the top five food retailers account for $60 \%$ of total sales (ACC, p. 5). Such concentration is also reflected globally as five corporations control 90 percent of the international grain trade, three countries produce 70 percent of exported corn, and the thirty largest food retailers control one-third of world grocery sales (McMichael, 2009, p.3)

Such concentration of profits from the consolidation and erasure of large farms and retailers is problematic and symptomatic. The former because the degree to which a commodity or group of commodities is economically concentrated demonstrates a consolidation of economic power, which can permit new forms of exploitation (Friedland 2003, p.6 and Buttel, 1983, p. 89). The latter points to the critical contradiction in capitalist accumulation. That is, driven by the competitive search for profit, mechanisation and other technological improvements are adopted that increase the composition of capital and average rate of profit. Given the dominance of the profit motive and incentives for expansion, over-production is endemic (Buttel, 1980, p. 88).

Indeed, Canada has benefitted from new production technologies that enable the separation of labour intensive production processes from the capital intensive ones (AAC 2006, p. 4). New transport and communication technologies facilitate the coordination of dispersed production and assembly establishments. The conjuncture of these two conditions has created a single world market for labour power, a true worldwide industrial reserve army and a single world market for production sites (Overbeek 2002, p.2). This is Pierre 
Bourdieu's 'global reserve army of labour' who are disposable, temporary, single, without social protection ideally suited to provide fill the dirty, dangerous, and demanding jobs in the neoliberal division of labour (2002a, pg. 40, as cited by Bauder 2006, p.5). Given that one third of producers in Canada are over the age of 55, this demographic deficiency coupled with the declining interest of the next generation to farm, raises the critical question, who will farm in Canada (p.5). Following seasonal agricultural work permits, it can be expected that Canada will continue to draw from an increasingly flexible and vulnerable labour pool to supplant the Canadian-born who use their labour market privilege to choose their occupations.

Indeed, although we are steeped in a discourse of the dictates of globalization, "so far this has meant attempts to enable the free flow of capital, information and services. Globalization has not involved a corresponding free movement of people across borders" (Arat-Koc, 1999, p. 40). The idea of mobility is as we have seen usually associated with the movement of capital more than of people. In the Americas, some twenty bilateral agreements have been signed since 1990 that serve to liberalise trade and investment between South, Central and North American countries. As Overbeek (2002) unequivocally announces, "here the emphasis is primarily on the subordination of migration management to the needs of capital" (p.10). These agreements share a number of regulations stipulating the mobility for people in so far as this movement is connected to capital mobility. The movement of capital requires some mobility of people as well, for labour market purposes, but also for access to land and to markets.

What's more is that today long-term control of large landholdings are seen as necessary to supply the food and energy needed to sustain consumption or impose it elsewhere into the future (Borras and Franco, 2003, p. 508). Canada too has stated objectives 
to increase 'Canadian presence' in the large markets of China and India in light of the fact that, "burgeoning middle classes with rising disposable incomes in these countries will demand greater range of value-added products... as these countries become more urbanized, demand for exotic, imported food products will grow over that of traditional, domestic foods" (The Canadian Agriculture and Agrifood Industry, AAC, 2006, p. 6). Creating and then satiating this demand through liberalization policies has deepened the conversion of the global South into a "world farm" for a minority of global consumers, concentrated in the global North and in strategic states and urban enclaves of the South (McMichael, 2009). Therefore, inasmuch as Canada actively seeks opportunities for pervasive market expansion it can be seen not only as complicit in the reproduction of global and national inequality but also, as an active participant in it.

Echoing historical land conquests or dispossessions, land is not exclusively under the auspices of national governments, further dismantling the symbolic construct of state sovereignty. In a neo-colonial reversal, capital is entering the Global South via long-term lease agreements on the most arable lands for export production to the 'renting country'. Such is the case with the South Korean company Daewoo that leased 1.3 million hectares of land for a contract of 99 years in Madagascar to grow corn (BBC 5 August 2009). Following much public inquiry and media coverage, soon after the new leader of Madagascar Andry Rajoelina cancelled the deal. Despite this cancellation, the increasing presence of land-rent schemes into Africa suggests a new colonial era, in which foreign direct investment directly reproduces capitalist relations of production within countries (Overbeek 2002 and McMichael 2009). Already, South Korea has acquired 690000 hectares of land to grow wheat in Sudan. The United Arab Emirates, which has 30000 hectares in Sudan, is investing in another 378000 hectares to grow corn, alfalfa, wheat, potatoes and beans. Following the 
buzz of bio-fuels, China has acquired 2.8 million hectares in the Democratic Republic of Congo to create the world's largest oil-palm plantation and is negotiating for two million hectares in Zambia to grow jatropha. British firms have secured big tracts of land in Angola, Ethiopia, Mozambique, Nigeria and Tanzania (Dyer, The Zimbabue Independent, 26 May 2009). Under these conditions, foreign direct investment becomes a functional alternative not only to trade but also to labour migration since the mobility of capital can substitute for the mobility of goods and labour power (Overbeek 2002, p. 3).

More problematically, rent schemes resound as a loud echo of the colonial era establishing an extractive relation between Europe and the rest of the world, whereby the fruits of empire displaced non-European provisioning systems, as the colonies were converted into supply zones of food and raw materials to fuel European capitalism (McMichael 2009, p. 2). To be sure, chains of exploitation also exist among countries of the Global South, analyses of which are well-merited but beyond the scope of this paper.

Land has always been coveted for multiple geopolitical reasons, historically. It is here that we see global capitalism making a full circle. Neo-colonial relations paradoxically are expected to redress initial inequalities in the formation of the world market. In the awesome 'creative destruction' that is capitalism, the term used initially to describe this process as a 'land grab' is slowly ceding ground to a new 'development'-land deals as a potential opportunity for rural development, provided that deals are negotiated in a way to minimize social and economic harm and maximize economic benefit, in order to then address social and economic harm. This is the illogic of disease as cure.

Under this guise, the hypocritical response of the meeting of agricultural ministers of the G8 in Treviso, Italy in July 2009 was to pledge to develop a proposal on principles and best practices' on purchases of land in developing countries (Kugelman 2009, p.11). The 
Food and Agricultural Organization of the United Nations (FAO) has also responded, not with condemnation or critique but rather with its own articulation of, "Principles for Responsible Agricultural Investment that Respects Rights, Livelihoods, and Resources" $(\mathrm{FAO}, 2010)^{11}$. These points for consideration for a "fair, inclusive outcome" or a win-win situation indicate adherence to a faulty logic that in collusion, exploitation can be mitigated by said 'best practices'. Such is the antimony of today's 'Codes of Conduct' or 'Corporate Social Responsibility'. The starting point for these negotiations is not who has or ought to have rights, to which land, for how long, and for what purposes instead the premise is successful national capitalist economic development accompanied by the implicit belief that rural poverty is the result of 'under productivity' or 'underutilization' (Borras and Franco, 2009 , p. 510). Put another way, countries of the Global South are poor because they have not followed the path to successful national development and alas, the full return to Rostow's modernization theory in development discourses. Furthermore, this colonialist assumption that said lands are bare or that nomadic groups are marginal to it, echoes Canada's own foundational, fictitious narrative of the two settler groups the English and the French. Similar to Canada's (non)education about Aboriginal peoples, such omissions contribute to a continual "learned ignorance" (Haig-Brown, as cited in Das Gupta et al, 2004, p. 169). The fact that we do not ask ourselves, as she proposes, "Whose traditional land are [we] on at this moment? What do [we] know of the past and present of peoples who traditionally dwelt here? [Most importantly,] whose interests are served when [we] cannot answer these questions" (p. 169) serves to justify continued occupation and a blaming of the victim fallacy. Such blaming precludes substantive proposals to guarantee food security and

${ }^{11}$ See http://unctad.ch/en/docs/ciicrp3_en.pdf. 
sovereignty for food insecure populations. In addition, asymmetrical attention is placed on the roles of either country as opposed to a wider, systemic dynamic that informs these roles.

\section{Conclusions: Mirage Multiculturalism, a Solvent Promise}

Why write a paper on food and immigration? Because questions of food are bound in latger questions of the failure of development, the under-achievement of food security, the degradation of the environment, the precarious nature of sustainability, and more calamitously, because food is essential to life, questions of dignity, life and death. As pleasure and solace, memory and culture, control and calculation, excessive and insufficient, accessible and unattainable, food provides a unique aperture into the 'malaises of modernity' (Taylor 1991) when 'simple' questions in fact reveal complex dynamics, processes, and symptoms: From what is our food made? From where? And by whom? As a universality, food reveals much about the differentiated migrated experience. For this reason, I believe this line of enquiry was both fruitful and added to the knowledge base about migration albeit from a different angle. In this analysis, I attempted to challenge borders that were permeable to food but impermeable to select types of labour.

To do so, this paper has set out to frame the relationship between institutions, ideologies, and material capabilities within the context of Canada's immigtation and agricultural policies. Using various tenets of Cox's historical structure and Zizek's typologies of ideology, it has been argued that human mobility and value is mitigated by neoliberal imperatives'. In doing so, this essay shed light on the aberrations of a doctrine that, only when human skills and culture can be commodified, do people attain the mobile status of commodities. 
By highlighting patterns of inequality in citizenship status and asymmetries in agricultural production and consumption, the multiple dimensions of power that combine to immobilize some and not others, were highlighted. In sum, three structures combine to govern mobility in Canada: the ideological, the institutional, and the material. Together and bridled by neoliberal ideology, the capitalist Canadian state has reneged on its promises of multiculturalism. It was argued that Canada's multiculturalism is effectively a mirage, the novelty of it is that in reproducing globalized inequality within its national borders, Canada reproduces its own image. That is, in nationalizing global inequality, Canada has fashioned a multicultural ideal from tattered political principles.

It was Marx who appreciates the very perversity and singularity of the achievement of capitalism to expropriate labour and extract a surplus value from it which explains the social activity of labour as power (Brown, 1995, p. 13). While much of the essay has emphasized ideology as organizing principle, it was not forgotten that behind this abstraction, "there are real people and natural objects on whose productive capacities and resources the capital's circulation is based and on which it feeds like a gigantic parasite" (Zizek 1998, p.2). Indeed, although ideologies are intangible, their effects are no less "real" Such is the fundamental and silent violence of capitalism, this violence is no longer attributable to concrete individuals and personal intentions, but is purely "objective", systemic, anonymous - "they know that, in their activity, they are following an illusion, but still, they are doing it" (Zizek, 1998, p. 2).

If the old adage is true, "we are what we eat", then under the project of global capitalism, we are only things-like food, we are grown and cultivated only to be bought and sold, expendable, replaceable by new trends or old prejudices, complete with disclaimers, allergy information, and contradictory messages about the suitability for health. 
Marx famously offered that, "Philosophers have interpreted the world in various ways, the point however is to change $i t^{\prime \prime}$. This essay then, is an academic attempt at illustrating another narrative, one that presents migration as related to food. In search of equality, it is my hope that this paper is the first of many in conversations and concerted efforts to chrystallize alternative histories and encourage always changeable worlds. 


\section{WORKS CITED}

Agriculture and Agrifood Canada (2005). Canadian Food Trends to 2020: A Long Range Consumer Outlook. Ottawa, Ontario. 10 April 2010. Retrieved From: www4.agr.gc.ca/resources/prod/doc/agr/pdf/ft-ta_eng.pdf

Agriculture and Agrifood Canada. (2006a). Next Generation of Agriculture and Agri-Food Policy. A Discussion Paper: The Canadian Agriculture and Agri-Food Industry. Ottawa, Ontario.

Agriculture and Agrifood Canada. (2006b). Next Generation of Agriculture and Agri-Food Policy: Economic Backgrounder: Changing Trends in the Agri-Food Chain.

Agriculture and Agrifood Canada (31 March 2008). SWOT Analysis of the Ethnic Food Sector in Ontario. Accessed 10 April 2010. Retrieved from: www.ethnicandspecialtyfood.com/.../AAFCEthnicFoodStudy-20080331-FINAL.pdf

Appadurai, A. (1988). How to Make a National Cuisine: Cookbooks in contemporary India. Comparitive Studies in Society and History. 30: 3-24.

Arat-Koc, S. (1999). Neo-Liberalism, State Restructuring and Immigration: Changes in Canadian Policies in the 1990s. Journal of Canadian Studies, 34 (2): 31-56.

Avakian, A (2005). "Shisk Kebab Armenians? Food and the Construction and Maintenance of Ethnic and Gender Identities among Armenian American Feminists" in From Betty Crocker to Feminist Food Studies: Critical Perspectives on Women and Food. Boston: University of Massachusetts Press, pp. 257-280.

Badiou, A. and Žižek, S. (2005). Philosophy in the Present. Malden: Polity.

Barthes, R. (2008). "Towards a Psychosociology of Contemporary Food Consumption" (pp.28-35) in Counihan, C and Van Esterik, P. (eds) Food and Culture. New York: Routledge.

Baetens, J. (2005). Cultural Studies after the Cultural Studies Paradigm. Cultural Studies 19 (1): $1-13$.

Bauder, H (2006). Labour Movement: How Migration Regulates Labour Markets. New York: Oxford.

Bauder, H. (2008) Citizenship as Capital. The Distinction of Migrant Labour. Alternatives: Global, Local, Political 33: 315-333.

Bhabha, Homi K. (1994). The Location of Culture. London: Routledge.

Bourdieu, P. (1984), Translated by Richard Nice. Social Critique of the Judgement of 'Taste. Cambridge: Harvard University Press. 
Borras Jr., S. and Franco, J. From Threat to Opportunity? Problems with the idea of a "Code of Conduct" for Land-Grabbing. Yale Human Rights and Developing Law Joumal. 13: 507-523.

Brown, W. (2006). Regulating Aversion. New Jersey: Princeton.

Brown, W. (1995). States of Injury. New Jersey: Princeton.

Butler, J. and Laclau and Žižek. (2000) Contingency, Hegemony, Universality. New York: Verso.

Buttel, Frederick H. and Newby, H. (1980). The Rural Sociology of the Advanced Societies. New Jersey: Allanhead, Osmun and Co. Publishers, Inc.

Cheng, S-J. "Labour Migration and International Sexual Division of Labor: A Feminist Perspective"

(pp. 38-58) in Gregory A. Kelson and Debra L. DeLaet (Eds.) Gender and Immigration. New York: New York University Press, 1999.

Cox, Robert W. (1996) "Social Forces, States and World Orders: Beyond International Relations Theory" in Cox, Robert W. and Sinclair, Timothy J. (eds.) Approaches to World Order. Cambridge University Press.

Conradson, D and Latham, A. (2005). Transnational Urbanism: Attending to Everyday Practices and Mobilities. Journal of Etbnic and Migration Studies 31(2): 227-233.

Cohen, R. (2006). Migration and its Enemies. Burlington, VT: Ashgate.

Cohn, Theodore H. (2005). Global Political Economy: Theory and Practise. $3^{\text {rd }}$ Ed. New York: Pearson Education.

Douwe van der Ploeg, J. (2010). The Food crisis, Industrialized Farming and the Imperial Regime. Joumal of Agrarian Change 10(1): 98-106.

DuPuis, M., and Goodman, D. (2002). "Knowing Food and Growing Food: Beyond the Production-Consumption Debate in the Sociology of Agriculture". Sociologia Ruralis $42(1): 5-22$.

Drummond, D and Fong, F. (8 March 2010). "TD Canada Trust Bank: Special Report: The Changing Canadian Workplace: Executive Summary". Accessed 20 April 2010. Available Online at: http://www.td.com/economics/special/ff0310_canlab.pdf

Dyer, G. (26 May 2009). African Land Grab. The Zimbabue Independent. Yale Global Online. Accessed: $\quad 10$ June 2010. Available Online at: http://yaleglobal.yale.edu/content/african-land

Elliot, C. (2008). "Consuming the Other: Packaged representations of Foreigness in 
President's Choice" in LeBesco, $\mathrm{K}$ \& Naccarato, P (Eds.), Edible Ideologies: Representing Food and Meaning. New York: State University of New York Press, pp. 179-198.

Fukuyama, F. (1992). The End of History and the Last Man. New York: Free Press.

Fukuyama, F. (1989). The End of History. The National Interest. 16.

Friedland, W.H (2003). Agrifood Globalization and Commodity Systems. International Joumal of Sociology of Agriculture and Food. XXXX: 5-16.

Girard, E., Bauder, H. (2007) Assimilation and Exclusion of Foreign Trained Engineers in Canada: Inside a Professional Regulatory Organization. Antipode. 39 (1): 35-53.

Gorz, A. (1999). Reclaiming Work. Malden, MA: Polity.

Gabriel, C. and Pellerin, H. (2008). Governing International Labour Migration. New York: Routledge.

Gillbert, J. (2008). "Against the Commodification of Everything". Cultural Studies 22 (5): 551566.

Gunew, S. (2000). "Introduction: Multicultural Translations of Food, Bodies, Language". Joumal of Intercultural Studies 21(3): 227-237.

Giminez, M. (2001). Marxism and Class, Gender and Race: Rethinking the Trilogy. Race, Gender, Class 8 (2): 23-33.

Haig-Brown, Celia (2007). Resistance and Renewal: First Nations and Aboriginal Education in Canada. (pp. 168-178) in Das Gupta T., James, C., and Maaka, R. (Eds.), Race and Racialization: Essential readings. Toronto: Canadian Scholars' Press.

Hamilton, S. (2009). "Analyzing Commodity Chains: Linkages or Restraints?" (pp. 16-25) in Belasco, W. and Horowitz, R. (eds). Food Chains: From Farmyard to Shopping Cart. Philadelphia: University of Pennsylvania Press.

Harvey, David. (1990) "Between Space and Time: Reflections on the Geographical Imagination." Annals of the Association of American Geographers 80: 418-34.

Harvey, D. (2005). A Brief History of Neoliberalism. New York: Oxford University Press.

Heldke, L. (2006). “The Unexamined Meal is Not Worth Eating". Food, Culture, and Society 9 (2): 202-219.

Hernandez-Ramdwar, C. (2008). Multigenerational and Food as Cultural Signifier: the Trinidadian Canadian Experience in Koc, M., MacRae, R., and Bronson, K (Eds.), Interdisciplinary Perspectives in Food Studies. Toronto: McGraw-Hill Ryerson. 
Hunt, K. (5 August 2009). Africa Investment Sparks land Grab Fear. BBC World News Senice. $\begin{array}{lllll}\text { Accessed } & 8 & \text { February } 2010 . & \text { Retrieved from: }\end{array}$ http://news.bbc.co.uk/2/hi/business/8150241.stm

Hudson, I and Hudson, M. (2003). Removing the Veil? Commodity Fetishism, Fair Trade, and the Environment. Organization and Environment 16(4): 413-430.

hooks, bell. (1992). Black Looks: Race and Representation. Boston, Massachusetts: South End Press.

Jhally, S. (1990). The Codes of Advertising: Fetishism and the Political Economy of Meaning in the Consumer Society. London: Routledge.

Johnston, J (2007). "Counter-hegemony or bourgeois piggery? Food politics and the case of FoodShare." (pp. 93-119) in Wright, W and Middendorf, G. (eds). The Fight Over Food: Producers, Consumers, and Activists Challenge the Global Food System. Pennsylvania: Pennsylvania State Press.

Kelley, N. and Trebilcock, M (1998). The Making of the Mosaic: A history of Canadian Immigration Policy. Toronto, Ontario: University of Toronto Press.

Kugelman, M. (2009). Introduction. (pp. 1-23) in Kugelman, M. and Levenstein, S. (eds). Land Grab: The Race for the World's Farmland. Woodrow Wilson International Centre for Scholars: Asia Program.

Koc, M. (2008). The Need for an Interdisciplinary Perspective in Food Studies: Introduction, (pp. 1-4) in Koc, M. MacRae, R., and Bronson, K. (Eds.), Interdiscplinary Perspectives in Food Studies Revised Edition. Toronto: McGraw-Hill Ryerson Ltd.

Lastarria-Cornhiel (2006). "Feminization of Agriculture: Trends and Driving Forces". RIMISP-Latin American Centre for Rural Development in preparation for the World Development Report 2008 "Agriculture for Development". Available online at: http://www.rimisp.org/getdoc.php?docid $=6489$

Levinas, I. (1989). "Ethics as First Philosophy," (pp. 75-87) in The Levinas Reader. S. Hand (ed.). Translated by S. Hand. Oxford: Basil Blackwell.

Lessa, I. \& Rocha, C. (2009). Nourishing belonging: Food in the lives of new immigrants in TO, in C. Palassio \& A. Wilcox (Eds.), The Edible City: Toronto's Food from Farm to Fork. Toronto: Coach House Books.

Morgan, K., Marsden, T., and Murdoch, J. (2006). Worlds of Food: Place, power, and Provenance in the Food Chain. New York: Oxford University Press.

FAO, IFAD, UNCTAD Secretariat and the World Bank Group. (March 2010). United Nations Conference on Trade and Development: Principles for Responsible Agricultural Investment that Respects Rights, Livelihoods and Resources. Accessed 10 June 2010. Retrieved From: http://unctad.ch/en/docs/ciicrp3_en.pdf. 
McMichael, M. (July-August 2009). The World Food Crisis in Historical Perspective. Monthly Review. Retrieved from: http://monthlyreview.org/090713mcmichael.php.

Lahav, G. \& Messina, A. (2006). The Migration Reader: Exploring Politics and Policies. Boulder: Lynne Rienner Publishers.

Oguz, S. (2005) "Reconsidering Globalization as the Internationalization of Capital: Implications for Understanding State Restructuring", paper presented at CPSA Annual Conference, University of Western Ontario, London.

Overbeek, H. (2002). Neoliberalism and the Regulation of Global Labor Mobility. The ANNALS of the American Academy of Political and Social Science 581: 74-90.

Patel, R. (2007). Stuffed and Starved. Toronto: Harper Collins.

Prashad, V (2007). The Darker Nations: A People's History of the Thitd World. New York: The New Press.

Peet, R. (2003). Unholy Trinity: the IMF, World Bank, and WTO. New York: Zed Books Ltd.

Preibisch, K. and Hermoso Santamaria, L. (2006) "Engendering Labour Migtation: The Case of Foreign Workers in Canadian Agriculture" (pp. 107-130) in Evangelia Tastsoglou and Alexandra Dobrowolsky (Eds.) Women, Migration and Citizenship: Making Local, National and Transnational Connections. Ashgate.

Reitz, J. (2005). 'Tapping Immigrants' Skills: New Directions for Canadian Immigration Policy in the Knowledge economky', IRPP, Choices 11 (1), Feb 2005. Retrieved from: http://www.irpp.org/endexe.htm

Panitch, L. (1994). "Globalization and the State", Socialist Register, New York: MRP, pp.6093.

Saloojee, A. (2003). "Social Inclusion, Anti Racism and Democratic Citizenship". Laidlaw Foundation Perspectives on Social Inclusion Series.

Sassen, S. (1996). Losing Culture? Sovereignty in an Age of Globalization. New York: Columbia University Press.

Smith, M P. (2005). Transnational Urbanism Revisited. Joumal of Ethnic and Migration Studies 31(2): 235-244.

Taylor, C. (1991). The Malaise of Modernity. Toronto: Anansi.

Teelucksingh, C and Galabuzi, G (2007). "Working Precariously: The Impact of Race and Immigrant Status on Employment Opportunities and Outcomes in Canada" (pp. 
202-208) in Tania Das Gupta et.al. (Eds.) Race and Racialization: Essential Readings. Toronto: Canadian Scholars' Press.

Vallinatos, H \& Raine, K (2008). "Consuming Food and Constructing Identities among Arabic and South Asian Immigrant Women". Food, Culture, and Society 11(3): 355-373.

Žižek, S. (2001). On Belief. New York, New York: Routledge.

Žižek, S. (1994). Mapping Ideology. New York: Verso.

Žižek, S. (2007). Badiou: Notes From an Ongoing Debate. International Journal of Zizek Studies $1(2): 1-15$ 